\title{
Seemingly Unrelated Regression Model of Economic Stability through a Combined Monetary Fiscal Policy in Indonesia
}

\author{
Ade Novalina ${ }^{1}$, Lia Nazliana ${ }^{2}$, Dede Ruslan ${ }^{3}$ \\ \{adenovalina@gmail.com ${ }^{1}$, lianazliana@gmail.com²,dras_ruslan@yahoo.com ${ }^{3}$ \} \\ ${ }^{1,2}$ Program Doktor Ilmu Ekonomi, Universitas Sumatera Utara \\ ${ }^{1}$ Universitas Pembangunan Panca Budi, Medan, Indonesia ${ }^{1}$ \\ ${ }^{3}$ Universitas Negeri Medan, Indonesia
}

\begin{abstract}
The research aims to analyze the influence of Seemingly Unrelated Regression (SUR), GOV, SBK to GDP in Indonesia, analyzing the influence in SUR, GOV, INF on GDP in Indonesia, analyzing the influence of the SUR GOV on the INF in Indonesia, analyzing the influence in the SUR SBK, JUB to GDP in Indonesia, analyzing the influence by SUR SBK towards JUB in this study uses quantitative material with the SUR approach. The quantitative material in this study was related to variable data that was observed that was GOV, SBK, INF, JUB and GDP in Indonesia year 2010 S/d 2018. The results of the analysis of SUR from the fiscal side to economic stability showed that Government Expenditure was positively influential but not significant to INF. Government Expenditure was positively influential but not significant to GDP, while inflation hurt economic growth. The monetary side shows that the interest rate of credit is positive but not significant to the amount of money supply. The interest rate of credit is negative but not significant to economic growth, while the amount of money supply has a positive effect on economic growth. The combined policy shows that Government Expenditure has a positive influence but is not significant to GDP as negative credit interest rate but is not significant to economic growth. It is not significant that the interaction of fiscal and monetary to economic growth shows the combined policy has not been effective in achieving economic stability in Indonesia. Thus, it is input for the Government and $\mathrm{BI}$ in coordinating the relevant combined policy to achieve economic stability.
\end{abstract}

Keywords: Government Expenditure, interest rate, inflation, money, GDP

\section{Introduction}

The importance of policy in a country to achieve economic stability as a benchmark is the fiscal policy and monetary policy on the economic fundamentals that are achieving stability of economic stability. The final goal of monetary policy is to maintain and maintain stability of the rupiah value, which is reflected in the low and stable rate of inflation. Bank Indonesia has an important role in maintaining long term stability [1]. The most common problem in developing countries is maintaining economic stability. A series of policies that governments do in economic stability are fiscal and monetary policies. Ideally, all policy endpoint goals can be achieved simultaneously and sustainably. However, in many countries including Indonesia, it is hard to achieve stabilization, even tend to mutually debilitating 
(contradictory) between one purpose and another [2]. Inflation can also be interpreted as rising prices of goods and services in general and continuously [3].

In emerging economies such as Indonesia, there is always a lack of balance between demand and bidding from the real sector. With the increase of the purchasing power injection into the economy, demand is increased, but the supply is relatively fixed due to structural rigidity, market imperfections. This leads to an inflationary price increase. In addition to the impact of government spending on output, another important aspect is the synchronization of fiscal policy with the economic business cycle. Ideally fiscal policy has the properties of an automatic economic stabilizer where the economic condition is undergoing expansion, then government expenditure should be reduced or the acceptance of increasing taxes.

Conversely if the economy is contraction, the fiscal policy should be expansive through increased spending or declining tax revenues, thereby automatic stabilizer of fiscal policy in the presence of the countercyclical function of fiscal policy [4]. According to the opinion above, it can be concluded that obtaining an efficient policy is to coordinate the policy (including international coordination) and to combine or combined the policies to achieve the objectives that have been established. The maturity of strategy and risk management is also needed to mitigate risk of unrest and so on in the economic maze. Therefore, this study will break down in such a way as to fiscal and monetary policy on economic fundamentals, as well as to explain the theoretical dynamics of both domestic and global macro-level security [5].

The rapidly developing countries (Emerging Market) nowadays generally have an economic structure that still patterned agriculture, which tends to be still very vulnerable by the shaking of economic activity. In countries such as Indonesia often occurs volatility in maintaining the balance of economic activity, always the most important concern because when the economy is unstable, conditions will arise economic problems such as low economic growth, investment, high exchange rate, and high rate of inflation. The size of the hub stability is where economic growth occurs; low currency rates tend to have a low rate of inflation [6].

The phenomenon of economic stability problems is more concrete by looking at the variable response of monetary, fiscal policy combined so that the empirical analysis has been titled "Seemingly Unrelated Model Regression economic stability through the Combined monetary fiscal Policy in Indonesia" in the research period 2000 S/d 2018), as follows:

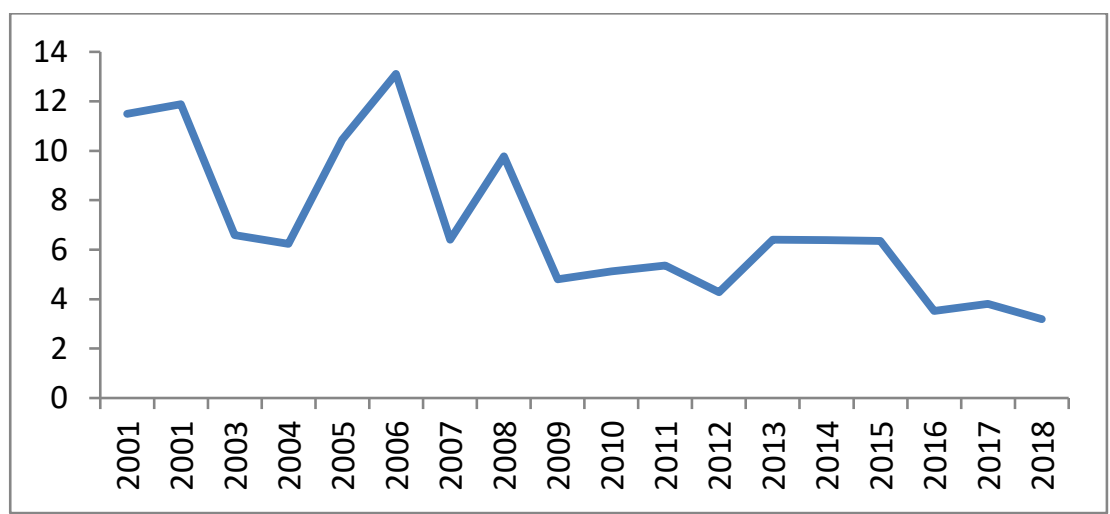

Fig 1. GDP in Indonesia 2001 - 2018 


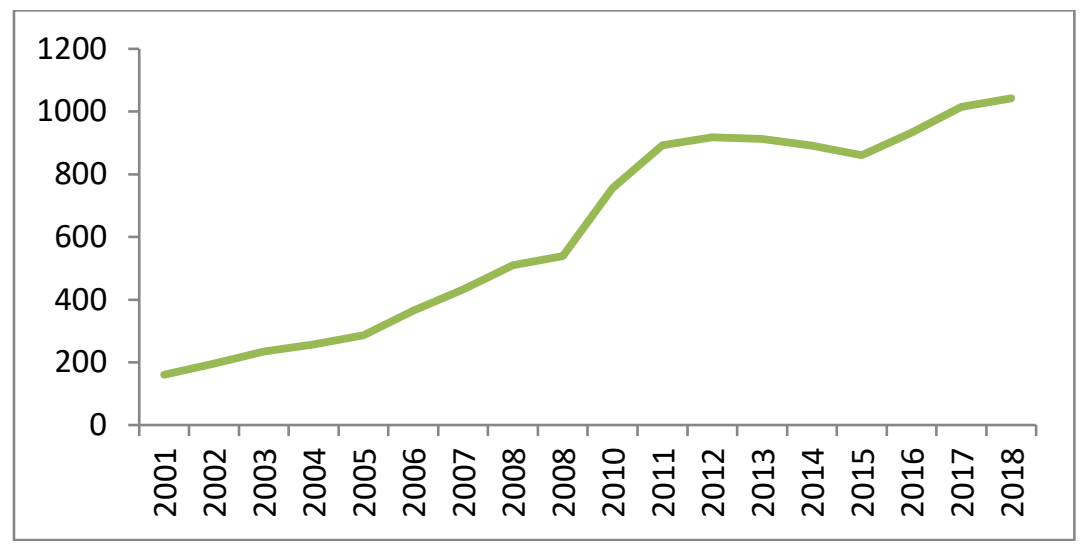

Fig 2. Inflation in Indonesia $2001-2018$

Data shows the economic growth of Indonesia tends to rise in the last twenty years, but during the economic crisis that occurred in the United States in 2008, it has affected inflation and slowdown Indonesia's economic growth in These periods, not achieving economic growth targets due to changes in fiscal and monetary policy, such as government spending changes, interest rate changes in the inflation stability efforts, but strongly affected Investment and greatly impacted the establishment of gross domestic product. From 2012 to 2015 even this year, Indonesia's economic growth also experienced slowdown or economic instability. The disruption of Indonesia's economic stability is the impact of the global economic crisis and the free-trade era, which causes fiscal and monetary policy changes such as government expenditure changes, changes in credit interest rates Impact investments, the amount of money supply, and inflation. Based on the phenomena, it is important to empirically analyze economic stability through the combined monetary policy in Indonesia by using the Seemingly Unrelated Model Regression

\section{Literature Review}

Economic stability is an economic condition in which there is no major change or fluctuations in macroeconomics, where the growth of its output remains, inflation is not more than $10 \%$ and often has a recession. Monetary policy is used to perform economic stability in the short term whereas fiscal policy is directed toward achieving the medium and long term economic targets [7]. The fiscal and monetary policies of each other are influential in economic activities.

The main variables of fiscal policy are TAX and GOV, while the monetary policy is JUB and SBI. This policy will affect economic stability, namely inflation, GDP, exchange rate, investment, and BP. Full disciplinary monetary and fiscal policies are recognized to play an important role in the highest level of inflation in the various economies of East and Southeast Asia. Coordination of monetary and fiscal policy becomes increasingly important when there is high uncertainty over the influence of each policy.

In practice we often encountered fiscal policy and also have monetary consequences or monetary policy with fiscal consequences. 


\section{Money market balance and goods market (IS *-LM *), Mundell-Fleming concept.}

A country's macroeconomic stability is capable of being controlled through fiscal and monetary policy. Control can be done if the government can predict the economic turmoil of the established monetary fiscal policy. In studying and analyzing and predicting economic phenomena a model or theory is required. The function of the model or theory is to help explain the economic phenomena. The macroeconomic models are often used to analyze how fiscal and monetary policies in the open economy are the Mundell - Fleming model. This model is described as a domain policy model for the study of monetary and fiscal policies on an open economy [7]. Decision-makers who ignore this influence will face danger [7]. The Mundell - Fleming model is the IS-LM model for the small open economy. This Model considers the price level to be certain (given) and then shows what causes fluctuations in revenues and exchange rates [7].

The item and Curve market IS * Mundell-Flaming describes the goods and services market as the IS-LM model, but this model adds new symbols for Net exports, so the IS * curve is a curve that shows the relationship of various levels of income and exchange rate that puts the market of goods and services in a balanced state, i.e. income equals to demand of goods and services. The higher the exchange rate than the lower the income level, assuming the capital mobility is perfect, so $\mathrm{R}=\mathrm{R} *$, obtained the following equation:

$$
\mathrm{Y}=\mathrm{C}+\mathrm{I}+\mathrm{G}+\mathrm{NX}[2.1]
$$

The equation is the equation of the intensity, which is the equation that must be properly seen from how the equation variables are spelled out [7]. To be more clearly seen: consumption depends positively on disposable income, which has the function of:

$$
\mathrm{C}=f(\mathrm{Y}-\mathrm{T})[2.2]
$$

Investment is the purchase of goods that will be used to produce more goods and services. Investments are the sum of the purchase of capital equipment, supplies, and buildings. Investments relate negatively to the interest rate, which has the function of:

$$
\mathrm{I}=f(\mathrm{r})[2.3]
$$

Government expenditure is the purchase of goods and services by local governments, centers that include wages of government work and spending for the public interest, denoted by G. Export Net is referring to the import value minus from the export value and related negatively with the exchange rate, which has the function of:

$$
\mathrm{NX}=f(\mathrm{e})[2.4]
$$

So that the results of the $\mathrm{C}, \mathrm{I}, \mathrm{G}$ and $\mathrm{NX}$ subtitling on acquired model IS *:

$$
\text { IS *: Y }=\mathrm{C}(\mathrm{Y}-\mathrm{T})+\mathrm{I}(\mathrm{r})+\mathrm{G}+\mathrm{NX}(\mathrm{e})[2.5]
$$

This equation states revenue is the amount of consumption, investment, government expenditure, and net export. The consumption of positive our relations on the disposable income, the investment relates negatively to the interest rate, and export of net is negatively related to the exchange rate. This equation is an IS * equation, which illustrates the balance of income and exchange rate on the market of goods and services.

The money market and the LM * curve on Mundell-Flaming IS explaining the money market as the IS-LM model. The LM curve * is a curve that shows the income level relationship on the various possible interest rates that put the money in a balanced state, i.e. money demand equals money supply, with the equation:

$$
\mathrm{M} / \mathrm{P}=\mathrm{L}(\mathrm{R}, \mathrm{Y})[2.6]
$$

This equation states that the offer of real money balance, $M / P$, equals the demand, $L(R$, Y). Demand for real money balance is negatively dependent on the interest rate, and positively on $\mathrm{Y}$ revenues. By adding the assumption that the domestic interest rate is equal to the world interest rate, the LM equation * becomes: 


$$
\mathrm{LM} *: \mathrm{M} / \mathrm{P}=\mathrm{L}(\mathrm{R} *, \mathrm{Y})[2.7]
$$

This equation shows a vertical LM* curve, as the exchange rate does not fit into the LM * equation. Based on the world interest rate, the LM equation * determines aggregate revenue, regardless of the exchange rate. The LM* Curve Associates an interest rate that follows the world interest rate and income [7]. From the equation, the interest rate is the domestic real interest rate that follows the world interest rate $(\mathrm{R} *)$, the real interest rate is a reduction in the nominal interest rate with inflation, illustrated in the equation:

$\mathrm{R} *=(\mathrm{i}-\pi)^{\prime}[2.8]$

The equation of equality [2.13] and [2.15] generates the IS *-LM * Balance Model:

IS *: Y $=\mathrm{C}(\mathrm{Y}-\mathrm{T})+\mathrm{I}(\mathrm{i}-\pi)+\mathrm{G}+\mathrm{NX}(\mathrm{e})[2.9 . \mathrm{A}]$

$\mathrm{LM} * \mathrm{M} / \mathrm{P}=\mathrm{L}((\mathrm{i}-\pi), \mathrm{Y})[2.9 . \mathrm{b}]$

Equation IS * Explains the balance in the goods market, and the LM equation * explains the balance in the money market. The balance for the economy where the IS curve * and LM curves * intersect. This intersection shows the exchange rate as well as the level of income in which the goods and money market in balance.

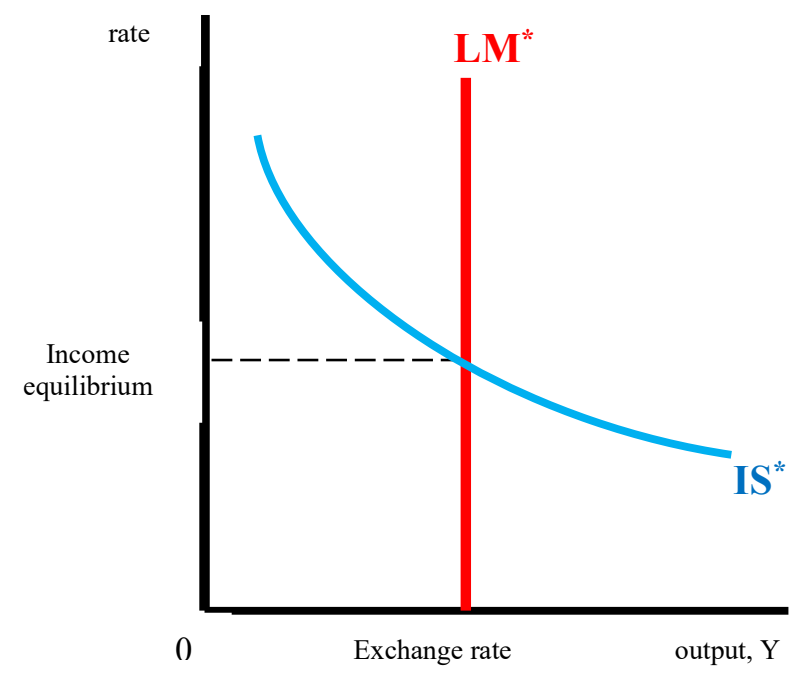

Fig 3. The IS curve balance * and the LM curve * (Model Mundell-Fleming) [7]

The equilibrium market of goods IS * and the equilibrium condition of the money market LM *. Both curves maintain a constant interest rate at the world interest rate. The second intersection of this curve indicates the level of income and exchange rate that meets the equilibrium both in the goods market and in the money market [7]. By using the model Mundell-Fleming to present how the aggregate revenue $\mathrm{Y}$ and $\mathrm{E}$ exchange rates respond to changes in fiscal policy and monetary policy. 


\section{Research Method}

This study uses quantitative material with the Seemingly Unrelated Regression (SUR) approach. The quantitative material in this study was related to the variable data that was observed, namely GOV, SBK, INF, JUB and GDP in Indonesia year 2000 - 2018.

The following is a description of the economic stability response through fiscal and monetary combined policy, while the shock occurring in economic growth became a benchmark for fiscal and monetary policy taking place. Based on theoretical foundations and previous research results, the conceptual framework in this study can be described as follows:

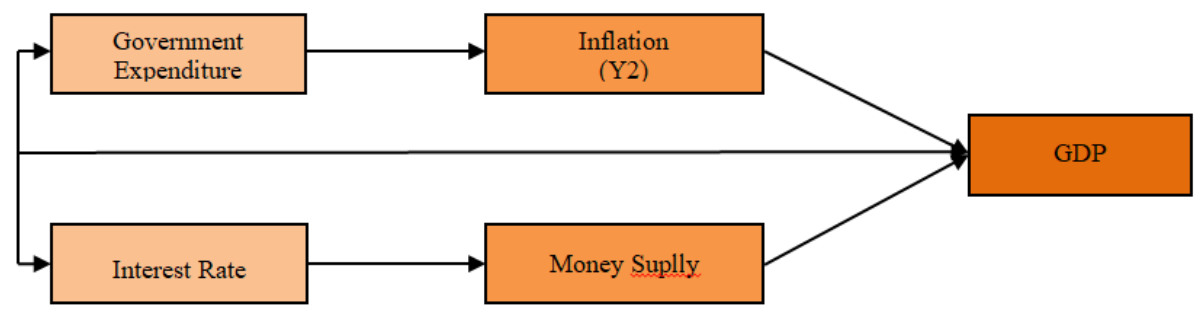

Fig 4. Research Method Seemingly Unrelated Regression

The analysis of data is adjusted to the economic stability through a combined policy of fiscal and monetary that is accommodated by the Seemingly Unrelated Regression approach. The scope of this research is focused on economic stability through the combined policy of fiscal and monetary with economic growth as the final target. The observed Data includes GOV, SBK, INF, JUB, and GDP. Data used in Indonesia data year $2001-2018$.

The method of data analysis used in this research is the Seemingly Unrelated Regression method. Based on the conceptual framework that has been built, there are 5 similarities in this model as follows:

Model Safety: $\quad$ Equation $1 \mathrm{PDB}=\mathrm{f}(\mathrm{GOV}, \mathrm{INF})$

Equation $2 \mathrm{PDB}=\mathrm{f}(\mathrm{SBK}, \mathrm{JUB})$

Equation $3 \mathrm{PDB}=\mathrm{f}(\mathrm{GOV}, \mathrm{SBK})$

Equation $4 \mathrm{INF}=\mathrm{f}(\mathrm{GOV})$

Equation $5 \mathrm{JUB}=\mathrm{f}(\mathrm{SBK})$

The five equations are transformed into the following forms of Economometric equations:

Econometric equations:

Equation $1 \log P D B=a 0+a 1 \log (G O V)+a 2 \log (I N F)$

Equation $2 \operatorname{LogPDB}=\mathrm{a} 0+\mathrm{a} 1 \log (\mathrm{SBK})+\mathrm{a} 2 \log (\mathrm{JUB})$

Equation $3 \log P D B=a 0+a 1 \log (G O V)+a 2 \log (S B K)$

Equation $4 \log I N F=a 0+a 1 \log (\mathrm{GOV})$

Equation $5 \operatorname{LogJUB}=\mathrm{a} 0+\mathrm{a} 1 \log (\mathrm{SBK})$

Then the analysis model used is Seemingly Unrelated Regression system with EVIEWS 7 program as follows:

Seemingly Unrelated Regression equations:

$\mathrm{GDP}=\mathrm{C}(10)+\mathrm{C}(11) * \mathrm{GOV}+\mathrm{C}(12) * \mathrm{INF}$

$\mathrm{GDP}=\mathrm{C}(20)+\mathrm{C}(21) * \mathrm{SBK}+\mathrm{C}(22) * \mathrm{JUB}$

$\mathrm{GDP}=\mathrm{C}(30)+\mathrm{C}(31) * \mathrm{GOV}+\mathrm{C}(32) * \mathrm{SBK}$

$\mathrm{INF}=\mathrm{C}(40)+\mathrm{C}(41) * \mathrm{GOV}$

$\mathrm{JUB}=\mathrm{C}(50)+\mathrm{C}(51) * \mathrm{SBK}$ 


\section{Results and Discussion}

Estimation to find out the influence of variables in 5 Seemingly Unrelated Regression equations is shown in the table below. From a known table 5 (five) equation model Seemingly Unrelated Regression as follows:

$$
\begin{aligned}
& \mathrm{GDP}=\mathrm{C}(10)+\mathrm{C}(11) * \mathrm{GOV}+\mathrm{C}(12) * \mathrm{INF} \\
& \mathrm{GDP}=\mathrm{C}(20)+\mathrm{C}(21) * \mathrm{SBK}+\mathrm{C}(22) * \mathrm{JUB} \\
& \mathrm{GDP}=\mathrm{C}(30)+\mathrm{C}(31) * \mathrm{GOV}+\mathrm{C}(32) * \mathrm{SBK} \\
& \mathrm{INF}=\mathrm{C}(40)+\mathrm{C}(41) * \mathrm{GOV} \\
& \mathrm{JUB}=\mathrm{C}(50)+\mathrm{C}(51) * \mathrm{SBK}
\end{aligned}
$$

Table.1: Seemingly Unrelated Regression:

System: Ade

Estimation Method: Seemingly Unrelated Regression

Date: $11 / 22 / 19$ Time: $12: 32$

Sample: 20012018

Included observations: 18

Total system (balanced) observations 90

Linear estimation after one-step weighting matrix

\begin{tabular}{lrrrr}
\hline & Coefficient & Std. Error & t-Statistic & Prob. \\
\hline $\mathrm{C}(10)$ & 1065.010 & 84.47553 & 12.60732 & 0.0000 \\
$\mathrm{C}(11)$ & 0.005738 & 0.022503 & 0.255001 & 0.7994 \\
$\mathrm{C}(12)$ & -64.00487 & 9.604461 & -6.664077 & 0.0000 \\
$\mathrm{C}(20)$ & 56.43275 & 209.5698 & 0.269279 & 0.7884 \\
$\mathrm{C}(21)$ & -0.366011 & 0.835929 & -0.437850 & 0.6627 \\
$\mathrm{C}(22)$ & 182.2896 & 61.21500 & 2.977859 & 0.0039 \\
$\mathrm{C}(30)$ & 640.2539 & 76.40517 & 8.379720 & 0.0000 \\
$\mathrm{C}(31)$ & 0.003930 & 0.010114 & 0.388537 & 0.6987 \\
$\mathrm{C}(32)$ & -0.380857 & 0.785778 & -0.484687 & 0.6293 \\
$\mathrm{C}(40)$ & 6.935622 & 0.705458 & 9.831369 & 0.0000 \\
$\mathrm{C}(41)$ & $4.89 \mathrm{E}-05$ & 0.000344 & 0.142100 & 0.8874 \\
$\mathrm{C}(50)$ & 3.172784 & 0.093199 & 34.04326 & 0.0000 \\
$\mathrm{C}(51)$ & 0.000676 & 0.001384 & 0.488210 & 0.6268 \\
& & & & \\
\hline
\end{tabular}

Determinant residual covariance

77774895

Equation: $\mathrm{PDB}=\mathrm{C}(10)+\mathrm{C}(11) * \mathrm{GOV}+\mathrm{C}(12) * \mathrm{INF}$

Observations: 18

R-squared

0.541731 Mean dependent var

622.2211

Adjusted R-squared

0.480628 S.D. dependent var

319.2407

S.E. of regression

230.0687 Sum squared resid

793974.1

Durbin-Watson stat

0.834769

Equation: $\mathrm{PDB}=\mathrm{C}(20)+\mathrm{C}(21) * \mathrm{SBK}+\mathrm{C}(22) * \mathrm{JUB}$

Observations: 18

R-squared

0.026618 Mean dependent var

622.2211

Adjusted R-squared

S.E. of regression

-0.103167 S.D. dependent var

319.2407

Durbin-Watson stat

335.3041 Sum squared resid

1686433 . 


\begin{tabular}{lrll} 
Equation: $\mathrm{PDB}=\mathrm{C}(30)+\mathrm{C}(31) * \mathrm{GOV}+\mathrm{C}(32) * \mathrm{SBK}$ & & \\
Observations: 18 & & & \\
R-squared & 0.042858 & Mean dependent var & 622.2211 \\
Adjusted R-squared & -0.084761 & S.D. dependent var & 319.2407 \\
S.E. of regression & 332.4951 & Sum squared resid & 1658295. \\
Durbin-Watson stat & 0.071114 & & \\
Equation: INF=C(40)+C(41)*GOV & & & 6.956666 \\
Observations: 18 & & & 3.052436 \\
R-squared & -0.008993 & Mean dependent var & 159.8197 \\
Adjusted R-squared & -0.072055 & S.D. dependent var & \\
S.E. of regression & 3.160495 & Sum squared resid & \\
Durbin-Watson stat & 0.929012 & & \\
Equation: JUB=C(50)+C(51)*SBK & & & 3.207778 \\
Observations: 18 & & & 0.260803 \\
R-squared & & & 1.150777 \\
Adjusted R-squared & 0.004786 & Mean dependent var \\
S.E. of regression & -0.057415 & S.D. dependent var & \\
Durbin-Watson stat & 0.268186 & Sum squared resid & \\
\hline & 1.430679 & & \\
\hline
\end{tabular}

Based on the results of the output equation, Seemingly Unrelated Regression can be known five equations, following each of the alignment in 5 equations:

\section{Equation Test result 1:}

The first equation is the equation used to know in Seemingly Unrelated Regression GOV, INF against GDP with the following equation as follows: $\mathrm{GDP}=\mathrm{C}(1)+\mathrm{C}(11) * \mathrm{GOV}+\mathrm{C}(12) * \mathrm{INF}$

Based on the equation, the output results in EViews with the Seemingly Unrelated Regression model as follows:

$$
\mathrm{PDB}=1065,01+0,0057 * \mathrm{GOV}-64,0048 * \mathrm{INF}
$$

\section{GOV coefficient}

It is known that the positive GOV coefficient is 0.0057 . Meaning that each GOV increase of 1 billion US \$, then GDP will increase by 0.0057 billion US \$. The probability value of $0.79>0.05$ implies that GOV does not significantly affect GDP. It can then be noted that Government Expenditure has a positive effect but is not significant to GDP.

\section{INF coefficient}

Known that the coefficient of INF negative 64.004. It means that any increase in INF by $1 \%$, then GDP will have decreased by 64.004 billion US \$. A probability value of $0.00<0.05$ contains the meaning that INF significantly affects GDP. It can be stated that inflation hurts economic growth.

The estimated result indicates that $\mathrm{R}^{\wedge} 2=0.5417$ that the GOV and INF were able to explain the GDP by $54.17 \%$, and the remainder of $45.83 \%$ PBD were influenced by other variables beyond the estimation in the model.

\section{Equation Test Result 2:}

The second equation is the equation used to know Seemingly Unrelated Regression SBK, JUB against GDP with the following equation as follows: 


$$
\mathrm{GDP}=\mathrm{C}(20)+\mathrm{C}(21) * \mathrm{SBK}+\mathrm{C}(22) * \mathrm{JUB}
$$

Based on the equation the output results in EViews with the Seemingly Unrelated Regression model as follows:

$$
\mathrm{GDP}=56,432-0,366 * \mathrm{SBK}+182,2898 * \mathrm{JUB}
$$

\section{SBK coefficient}

It is known that the SBK coefficient is 0.366 negative. Meaning that each SBK increase by 1 percent, GDP will decrease by 0.366 billion US $\$$. The prob value of $0.66>0.05$ implies that the SBK does not significantly affect GDP. It can be stated that the credit interest rate is negative but not significant to GDP.

\section{JUB coefficient}

It is revealed that the positive JUB coefficient is 182.28. It means that any JUB enhancement of $1 \%$ of GDP, then GDP would have increased by 182.28 billion US \$. A prob value of $0.005<0.05$ implies that JUB significantly affects GDP. It can be stated that the money supply has a positive effect on economic growth.

The estimated results showed that $\mathrm{R}^{\wedge} 2=0.0266$ that the SBK and JUB were able to explain the GDP by $2.66 \%$, and the remainder of $97.34 \%$ PBD were influenced by other variables beyond the estimation in the model.

\section{Equation 3 test Result:}

The third equation is the equation used to know Seemingly Unrelated Regression GOV, SBK against GDP with the following equation as follows:

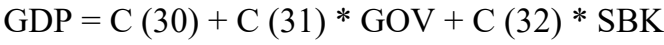

Based on the equation the output results in EViews with the Seemingly Unrelated Regression model as follows:

$$
\mathrm{GDP}=640.253+0,003 * \mathrm{GOV}-0,380 * \mathrm{SBK}
$$

\section{GOV coefficient}

It is known that the positive GOV coefficient is 0.003 . Meaning that each GOV increase of 1 billion US \$, then GDP will have an increase of 0.003 billion US \$. The probability value of $0.69>0.05$ implies that GOV does not significantly affect GDP. It can then be noted that Government Expenditure has a positive effect but is not significant to GDP.

\section{SBK coefficient}

It is known that the SBK coefficient is 0.380 negative. Meaning that each SBK increase is $1 \%$, GDP will have decreased by 0.380 billion US \$. The probability value of $0.62>0.05$ implies that the SBK does not significantly affect GDP. It can be stated that the credit interest rate is negative but not significant to economic growth. The estimated results showed that $\mathrm{R}^{\wedge}$ $2=0.0428$ that the GOV and SBK were able to explain the GDP by $4.28 \%$, and the remainder of $95.72 \%$ PBD were influenced by other variables beyond the estimation in the model.

\section{Equation 4 test Result:}

The fourth equation is the equation used to know in Seemingly Unrelated Regression GOV against inflation with the following equation as follows: INF $=\mathrm{C}(40)+\mathrm{C}(41) * \mathrm{GOV}$

Based on the equation the output results in reviews with a Seemingly Unrelated Regression model as follows:

$$
\mathrm{INF}=6,935+4.89 * \mathrm{GOV} \text {. }
$$


It is known that the positive GOV coefficient is 4.89 . It means that any increase in GOV of 1 billion US \$, then INF will experience an increase of $4.89 \%$. The value of prob $0.88>$ 0.05 implies that the GOV does not significantly affect the INF. It can be stated that Government Expenditure has a positive effect but is not significant to inflation. The estimated results showed that $\mathrm{R} \wedge 2=0.0089$ that the GOV was able to explain inflation was only $0.89 \%$, and the remainder of $99.11 \%$ INF was influenced by other variables beyond the estimation in the model.

\section{Equation Test Result 5:}

The fifth equation is the equation used to know Seemingly Unrelated Regression SBK against JUB with the following equation as follows:

$$
\mathrm{JUB}=\mathrm{C}(50)+\mathrm{C}(51) * \mathrm{SBK} .
$$

Based on the equation, the output results in EViews with the Seemingly Unrelated Regression model as follows:

$$
\mathrm{JUB}=3.172+0.006 * \mathrm{SBK} .
$$

Note that SBK coefficient is 0.00069 positive, meaning that each SBK increase by 1 percent then the money supply will increase by $0.0006 \%$ of GDP. The probability value of $0.62>0.05$ means that the interest of not significantly affects JUB. It can be stated that the credit interest rate is positive but not significant towards JUB. The estimated result shows that $\mathrm{R}^{\wedge} 2=0.0047$ that SBK is capable of explaining the money supply is only $0.47 \%$, and the remaining $99.53 \%$ JUB is influenced by other variables beyond the estimate in the model.

Seemingly Unrelated Regression Analysis considers the influence of fiscal and monetary policy on economic stability with the final target of economic growth, described as follows: seen from the fiscal side to economic stability On the Seemingly Unrelated Regression Model, by looking at expenditure Government influence on inflation and the Government influence of Expenditure, inflation on economic growth. The results of the study stated that Government Expenditure was positively influential but not significant to inflation. Government Expenditure has positive influence but is not significant to GDP, while inflation hurts economic growth.

While judging from the monetary side of economic stability on the Seemingly Unrelated Regression Model at the influence of credit interest rates on the amount of money supply and the influence of interest rate credit, the amount of money supply to economic growth. Monetary policy with a monetary pricing approach can have an effective effect on controlling the inflation rate through interest rate channels and exchange rates [10].

The results of the study stated that the credit interest rate was positive but not significant to the amount of money supply. The interest rate of credit is negative but not significant to economic growth, while the amount of money supply has a positive effect on economic growth. Money has been affected by the economic growth and inflation movements, interest rates are negative and significant to inflation that can be seen from the fiscal and monetary side to economic stability on the Seemingly Unrelated Regression Model, by looking at the Government influence of exhaled, interest rate credit against economic growth. The results of the study stated that Government Expenditure was positively influential but not significant to GDP, a negative interest rate of credit, but not significant to economic growth. 


\section{Conclusion}

Based on the results of the research and the discussion can be concluded Seemingly Unrelated Regression from the fiscal side to economic stability by looking at the influence of expenditure Government to inflation and the influence of the Government Expenditure, inflation To economic growth, showed that Government Expenditure was positively influential but not significant to INF. Government Expenditure was positively influential but not significant to GDP, while inflation negatively affected economic growth. Results of the analysis of Seemingly Unrelated Regression from the monetary side to economic stability by looking at the influence of credit interest rates on the amount of money supply and the influence of credit interest rate, the amount of money supply to economic growth, indicating That the credit interest rate is positive but not significant to the amount of money supply. The interest rate of credit is negative but not significant to economic growth, while the amount of money supply has a positive effect on economic growth. Results of the analysis of Seemingly Unrelated Regression from the fiscal and monetary side to economic stability by looking at the Government influence of Excalibur, interest rate credit on economic growth, showed that the influential Government Expenditure Positive but not significant to GDP, the rate of credit is negative, but not significant to economic growth. It is not significant that the interaction of fiscal and monetary to economic growth shows the combined policy has not been effective in achieving economic stability in Indonesia. Thus, it is input for the Government and BI in coordinating the relevant combined policy to achieve economic stability.

\section{Reference}

[1] Rusiadi. Analisis Efektivitas Transmisi Kebijakan Moneter Jangka Panjang Dalam Menjaga Stabilitas Ekonomi Negara Emerging Market. (2018).

[2] Natsir, B. Ekonomi Moneter dan Kebanksentralan. Mitra Wacana Media. Jakarta. (2014).

[3] Suseno and Aisyah, S. Inflasi. Pusat Pendidikan dan Studi Kebanksentralan (PPSK) Bank Indonesia. Jakarta. (2009).

[4] Jhingan, M. L. Ekonomi Pembangunan dan Perencanaan. PT. Raja Grafindo Persada. Jakarta. (2003).

[5] Bollard, A. Where we are going with macro and micro-prudential policies in New Zealand. (2011).

[6] Novalina, A. Prediksi Stabilitas Ekonomi (Vol. 5). Jepa. Medan. (2018).

[7] Mankiw, N. G. Principles of Macroeconomics. Thompson Higher Education. USA. (2007).

[8] Rusiadi, d. R. Metode Penelitian Manajemen, Akuntansi dan Ekonomi Pembangunan, Konsep, Kasus dan Aplikasi SPSS, Eviews, Amos dan Lisrel. USU Press. Medan. (2015).

[9] Nguyen, E. Monetary Policy Transmission in the Tunisian Banking Sector. National Bank of Poland. (2016).

[10] Hai, B.V., and Trang, T.T.M. The Transmission Mechanism of Monetary Policy in Vietnam: A VAR Approach. The Graduate Institute of International and Development Studies Geneva. (2015).

[11] Havránek, T., And Rusnák, M. Transmission Lags of Monetary Policy: A MetaAnalysis. Czech National Bank. (2012). 
[12] Hussain, Z. A.N. The Lags in Effect Of Monetary Policy: A Case Study Of Pakistan. Pakistan Economic And Social Review. (2014).

[13] Hsing. Y. Monetary Policy Transmission And Bank Lending In China And Policy Implications. Journal Of Chinese Economics. (2015).

[14] Naomi, Godwin Chukwudum. The Balance of Payments as a Monetary Phenomenon: An Econometric Case Study of Nigeria. JEL Classification. (2003).

[15] Odo, A.C., Odiony, J.K., and Ojike, R.O. Inflation Dynamics In Nigeria: Implications For Monetary Policy Response. Journal of Economics and Sustainable. (2016).

[15] Oliner, S.D. dan Rudebusch, G. D. Is There a Broad Credit Channel for Monetary Policy? FRBSF Economic Review. (2014).

[17] Forhad, A.R., Homaifar, G.A. and Salimullah, A.S.M. Monetary Policy Transmission Effect On The Realsector Of The Bangladesh Economy: An Svar Approach. Economia Internazionale / International Economics. (2017).

[18] Rosoiu A. Emerging Markets Queries Monetary Policy And Time-Varying Parameter Vector Autoregression Model. The Bucharest University of Economic Studies, Procedia Economics, and Finance. (2015).

[19] Shenglin, N.Y.G., and Ben. Should Practice Simple Central Banking To Help Rmb Internationalization. Journal Of Chinese Economics. (2016). 